\title{
IRF4 and STAT3 activities are associated with the imbalanced differentiation of T- cells in responses to inhalable particulate matters
}

Jinzhun Wu ${ }^{1,2+}$, Dandan Ge ${ }^{1,3,4 \dagger}$, Taoling Zhong ${ }^{5}$, Zuojia Chen ${ }^{6}$, Ying Zhou' ${ }^{5}$, Lingyun Hou ${ }^{5}$, Xiaoliang Lin ${ }^{1,3,4}$, Jiaxu Hong ${ }^{7,8,9}$, Kuai Liu ${ }^{5}$, Hui Qi ${ }^{10}$, Chaoying Wang ${ }^{10}$, Yulin Zhou ${ }^{2}$, Cheng $\mathrm{Li}^{11}$, Chuan Wu ${ }^{6}$, Shuiping Wu ${ }^{12}$, Zuguo Liu' ${ }^{11^{*}}$ and Qiyuan Li' ${ }^{1,5^{*}}$ (D)

\begin{abstract}
Background: Particulate Matter (PM) is known to cause inflammatory responses in human. Although prior studies verified the immunogenicity of PM in cell lines and animal models, the effectors of PM exposure in the respiratory system and the regulators of the immunogenicity of PM is not fully elucidated.

Methods: To identify the potential effector of PM exposure in human respiratory system and to better understand the biology of the immunogenicity of PM, We performed gene-expression profiling of peripheral blood mononuclear cells from 171 heathy subjects in northern China to identify co-expressed gene modules associated with PM exposure. We inferred transcription factors regulating the co-expression and validated the association to Tcell differentiation in both primary T-cells and mice treated with PM.

Results: We report two transcription factors, IRF4 and STAT3, as regulators of the gene expression in response to PM exposure in human. We confirmed that the activation of IRF4 and STAT3 by PM is strongly associated with imbalanced differentiation of T-cells in the respiratory tracts in a time-sensitive manner in mouse. We also verified the consequential inflammatory responses of the PM exposure. Moreover, we show that the protein levels of phosphorylated IRF4 and STAT3 increase with PM exposure.
\end{abstract}

Conclusions: Our study suggests the regulatory activities of IRF4 and STAT3 are associated with the Th17-mediated inflammatory responses to PM exposure in the respiratory tracts, which informs the biological background of the immunogenicity of particulate matters.

Keywords: Particulate matters, Gene expression profiling, Allergic respiratory disease, Imbalanced T-cell differentiation, Transcription factor

\footnotetext{
* Correspondence: zuguoliu@xmu.edu.cn

${ }^{\dagger}$ Jinzhun Wu and Dandan Ge contributed equally to this work.

${ }^{11} F u j i a n$ Provincial Key Laboratory of Ophthalmology and Visual Science, Eye

Institute of Xiamen University, School of Medicine, Xiamen University,

Xiamen 361102, China

'Department of Pediatrics, the First Affiliated Hospital of Xiamen University, Xiamen 361003, China

Full list of author information is available at the end of the article
}

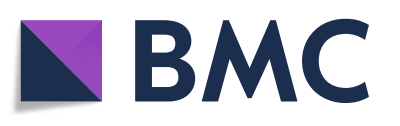

(- The Author(s). 2020 Open Access This article is licensed under a Creative Commons Attribution 4.0 International License, which permits use, sharing, adaptation, distribution and reproduction in any medium or format, as long as you give appropriate credit to the original author(s) and the source, provide a link to the Creative Commons licence, and indicate if changes were made. The images or other third party material in this article are included in the article's Creative Commons licence, unless indicated otherwise in a credit line to the material. If material is not included in the article's Creative Commons licence and your intended use is not permitted by statutory regulation or exceeds the permitted use, you will need to obtain permission directly from the copyright holder. To view a copy of this licence, visit http://creativecommons.org/licenses/by/4.0/. The Creative Commons Public Domain Dedication waiver (http://creativecommons.org/publicdomain/zero/1.0/) applies to the data made available in this article, unless otherwise stated in a credit line to the data. 


\section{Introduction}

Particulate Matter (PM) is a major cause of air pollution and a risk factor to public health. In 2015, 4.241 million deaths worldwide are attributable to ambient particulate matter [1], which is ranked the 6th of the 10 largest hazard factors contributing to the global disabilityadjusted life-years (DALYs) [1]. Epidemiological studies conducted in different regions of the world confirm that PM is associated with elevated incidences of various human diseases, including cardiovascular disease [2, 3], lung cancer $[4,5]$, chronic obstructive pulmonary disease (COPD) [6], Atopic dermatitis (AD) [7, 8], hypertension [9], type 2 diabetes [10], dry eye [11], allergic rhinitis [12] and asthma [13].

$\mathrm{PM}$ is classified into three subtypes, $\mathrm{PM}_{2.5}, \mathrm{PM}_{10}$ and ultra-fine particles (UFP), according to the aerodynamic diameters. The physical-chemical properties of PM differ according to the geological locations, the subtypes and the sources. Most of the natural PM particles consist of mineral dusts, metal and ammonium salts. Anthropogenic PM, however, consists mainly particles of black carbon, various organic and inorganic residues of combustion of fossil fuels or coals. PMs are generated from oxidation of primary airborne pollutants such as sulfur and nitrogen oxides, which is also known as secondary particles [14]. Moreover, PM absorbs other airborne molecules such as heavy metals, polycyclic aromatic hydrocarbons (PAHs) in the surface.

Exposure to PM are proved to be toxic to humans. Although the biological background of the toxicity of PM is not fully elucidated, most evidences suggest several biological processes are involved in the cells' responses to PM. First, PM cause various immune responses in human tissues. In vitro and in vivo analyses suggest that PM induces neutrophils, eosinophils as well as macrophages by activating pro-inflammatory cytokines, such as IL8, IL1 $\beta$ and GM-CSF, which trigger a series of inflammatory responses. In addition, PM activates Th2-related cytokines (IL-33, ST2) while suppresses Th1-related cytokines (INF- $\gamma$ ), which leads to the imbalance among T-helper cells. Two transcription factors, GATA3 and T-bet are shown to be associated with the responses to the exposure of PM in mice but the observations are not statistically significant [15]. Moreover, exposure to PM also causes oxidative stress, which is mediated by Nrf2 in the PIK3/AKT signaling pathway [16]. Plus, PM also induces apoptosis and autophagy via TNF- $\alpha$ and caspase signaling [17].

Respiratory tracts, which interact directly with inhalable PM, are the major site of PM deposition in human body. Many prior evidences claim that the exposure is associated with allergies in the respiratory tracts, such as chronic obstructive pulmonary disease (COPD) [6], allergic rhinitis [12] and asthma [13]. However, most of the evidences are based on cell lines and mice; and less is known about how cells react to PM exposure in human.

To fully assess the effects of PM on human respiratory tracts, we generated a peripheral blood geneexpression profiles of a healthy population under PM exposure; we developed an integrated method to infer specific transcription factors that modulate $\mathrm{T}$-cell response to the PMs and verified the effects of PM on $T$-cell differentiation in vitro and in vivo. Our study reveals the biological background of the immunogenicity of PM and helps to understand the toxicity of $\mathrm{PM}$ in allergic respiratory disease.

\section{Materials and methods Study cohort}

The subjects are randomly chosen from healthy individuals who were enrolled in physical examinations in three cities in northern China, Beijing, Taiyuan and Shijiazhuang. All subjects are from Chinese population without recorded underlying diseases. The collection and usage of the patients' peripheral blood sample has received written consent. This study protocol and informed consent form were overseen and approved by a steering committee, institutional review boards of Xiamen University and the First Affiliated Hospital of Xiamen University. All methods were carried out in accordance with the relevant guidelines and regulations.

The air quality record of the three cities during the study period, including daily concentration of $\mathrm{CO}, \mathrm{SO}_{2}$, $\mathrm{NO}_{\mathrm{x}}, \mathrm{PM}_{10}$ and $\mathrm{PM}_{2.5}$, is available from the Ministry of Environmental Protection of the People's Republic of China (www.mee.gov.cn).

\section{Gene expression profiling}

Total RNA was isolated from human peripheral blood mononuclear cells (PBMCs) and hybridized to the Illumina single color Human BeadChip HT12 v4 whole genome expression array. The gene expression profiles were analyzed using the "limma" package available in R-3.5. Genes with significant detecting power $(P<0.05)$ were selected for further statistical analyses.

\section{Statistical analysis \\ Deriving co-expressed gene modules}

We used weighted gene co-expression network analysis (WGCNA) to generate a co-expression subnetwork of genes from the expression profiles [18]. Then we calculated the Spearman's rank correlation coefficients between the module eigengenes and the concentrations of $\mathrm{PM}_{2.5}, \mathrm{PM}_{10}$ and other pollutants such as $\mathrm{CO}, \mathrm{SO}_{2}$ and $\mathrm{NO}_{\mathrm{x}}$. We then used "TFactS" to predict transcription factors of which the activity is significantly enriched in each co-expression modules (FDR < 0.1) [19]. 


\section{Motif analysis}

For each gene in a co-expressed module, we retrieved the genomic DNA sequences corresponding to the DNaseI hypersensitivity sites (DHS) located within 5 kilobases of either side of the transcription starting sites (TSS). The location of DNase I hypersensitivity sites are based on Digital DNaseI Hypersensitivity Clusters from ENCODE [20]. Then we used HOMER (version 4.9) to evaluate the enrichment of known transcription-factor-binding motifs [21]. As the activities of the transcription factors are tissue specific, we only keep significantly enriched motifs (FDR < 0.1 ) in relevant T-cell types.

\section{Particles}

Ambient PM (aerodynamic diameter $\leq 10 \mu \mathrm{m}$ ) were collected in an urban area of Xiamen, China using a highvolume ultrafine particle sampler with a Zefluor filter. After collection, PM was dehydrated and dispersed the $\mathrm{PM}$ in $2 \mathrm{mg} / \mathrm{ml}$ Sodium carboxymethylcellulose (CMC) ultrasonically. A total of eight water soluble ions $\left(\mathrm{Cl}^{-}\right.$, $\mathrm{NO}^{-}, \mathrm{SO}_{2} 2^{-}, \mathrm{Na}^{+}, \mathrm{NH}^{+}, \mathrm{K}^{+}, \mathrm{Mg}^{2+}$, and $\mathrm{Ca}^{2+}$ ) were analyzed by ion chromatography. A portion of filter sample was digested for element measurement $(\mathrm{K}, \mathrm{Ca}, \mathrm{Mg}, \mathrm{Al}, \mathrm{Fe}$, $\mathrm{Be}, \mathrm{V}, \mathrm{Cr}, \mathrm{Mn}, \mathrm{Ni}, \mathrm{Cu}, \mathrm{Zn}, \mathrm{As}, \mathrm{Se}, \mathrm{Cd}, \mathrm{Ba}$, and $\mathrm{Pb}$ ) using inductivity coupled plasma-mass spectrometry (ICP-MS) (7700X, Agilent). An area of $0.49 \mathrm{~cm}^{2}$ punched from each quartz filter was analyzed for organic carbon $(\mathrm{OC})$ and elemental carbon (EC) fractions using a DRI model 2001 carbon analyzer (Atmoslytic, Calabasas, CA).

To assess the proportion of $\mathrm{PM}_{2.5}$ and $\mathrm{PM}_{10}$ in our sample, we studied the distribution of the diameters of the particulates in the PM sample used for the in vivo experiments by microscope observation.

In addition, the protease activity of PM was measured by Protease Fluorescent Detection Kit (PF0100, Sigma) following protocols described by the manufacturer. We used the $50 \mathrm{ng}$ and $30 \mathrm{ng}$ Trypsin Control as the standard sample, and the loading concentration of PM sample is $10 \mathrm{mg} / \mathrm{ml}$. A reading equal to $120 \%$ of the value obtained with the blank sample (0 ng trypsin) is considered significant.

\section{In vitro analysis}

Single naive $\mathrm{CD} 4^{+} \mathrm{T}$-cells were isolated from the mouse $(\mathrm{BALB} / \mathrm{c})$ spleen aged $8-10$ weeks and purified by CD4 (L3T4) MicroBeads. Isolated $\mathrm{CD}^{+}{ }^{+} \mathrm{T}$-cells were stimulated with $5 \mu \mathrm{g}$ of plate-bound anti-CD3 and $1 \mu \mathrm{g} / \mathrm{ml}$ of soluble anti-CD28.After co-cultivation with PM for $48 \mathrm{~h}$, T-cell differentiation was analyzed using BD LSRFortessa ${ }^{\text {Tw }}$ flow cytometer following standard protocols (Additional file 1).

\section{Animal model}

Wild type BALB/c mice (female, 6-8 weeks) were obtained from the Xiamen University Laboratory Animal
Center (XMULAC). All mice were maintained under specific pathogen-free (SPF) condition. The animal experiment was approved by the Institutional Animal Care and Use Committee (Laboratory animal license: SYXK (Min) 2018-0010) and was in accordance with good animal practice as defined by the XMULAC (Xiamen Univerisity Laboratory Animal Center).

Mice $(\mathrm{BALB} / \mathrm{c})$ were randomly divided into two groups. The treatment group was given $40 \mu \mathrm{PM}$ suspension (containing $100 \mu \mathrm{g}$ PM) intranasally for 3 consecutive days, and the control group was given $40 \mu \mathrm{l}$ $\mathrm{NaCl}$ solution. All the mice were anesthetized through nose with isoflurane before dripping.

\section{Flow Cytometry analysis}

We sacrificed the mice at $18 \mathrm{~h}, 24 \mathrm{~h}, 40 \mathrm{~h}$, and $72 \mathrm{~h}$ after the last nasal drip. Then we harvested the lung tissue and collected the lymphocytes for flow cytometry analysis (Additional file 1).

\section{ELISA, quantitative real-time $P C R$ and Western blotting}

We sacrificed the mice at $24 \mathrm{~h}$ after the last nasal drip. To measure cytokines expression, we performed capture ELISA for IL-17A, IL-21, IL-22, IL-4 and IL-13 in supernatants of primary T-cells, blood and bronchoalveolar lavage fluid (BALF) from mice treated with PM suspension by Meso-Scale Discovery (MSD) platform (K151VBK-1, sensitivity $<0.6 \mathrm{pg} / \mathrm{ml}$ ), univ-bio, Shanghai, China.

To measure the transcript levels of relevant genes (Irf4, Batf, Stat3, IL-4), we performed quantitative real-time PCR was performed using SYBR green-based reagents on the ViiA 7 Real-Time PCR System (Life Technologies) with primer pairs targeting the cDNAs of interests (see Additional file 1: Table S1). All qPCR reactions were run in duplicates and the resulted CT values were normalized to $\beta$-actin (Additional file 1).

Phosphorylated and unphosphorylated STAT3 and IRF4 in mouse lung were separated by SDS-polyacrylamide gel electrophoresis then western blotting was conducted using IRF4 (D9P5H) Rabbit mAb, phospho-STAT3 (Tyr705) (M9C6) Mouse mAb, STAT3 (124H6) Mouse mAb and phospho-IRF4 (Phospho-Tyr122/125) antibody.

\section{Results}

Co-expressed gene modules correlated with PM exposure We enrolled 171 healthy subjects from three cities in northern China, namely, Beijing, Taiyuan and Shijiazhuang (Fig. 1a). These cities are highly homogeneous in terms of the geographic features and climatic conditions. To measure the exposure to the PM and other pollutants, we calculated the average concentrations of five pollutants $\left(\mathrm{PM}_{2.5}, \mathrm{PM}_{10}, \mathrm{CO}, \mathrm{NO}_{2}, \mathrm{SO}_{2}\right)$ within 21 days preceding the collection of the blood sample in each city (Fig. 1b, see Additional file 1: Figure S1, and Table 1). 


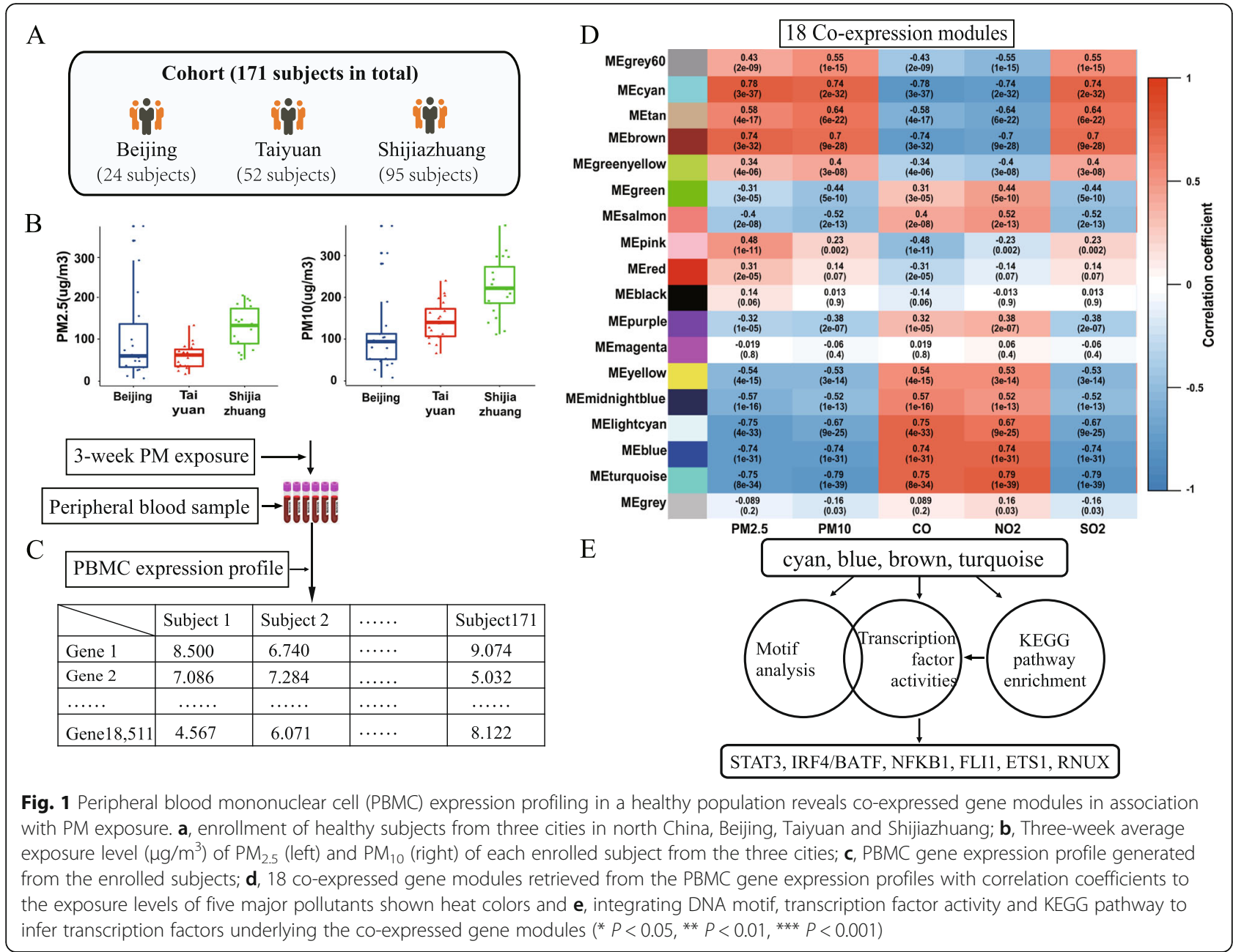

According to the U.S. Environmental Protection Agency (EPA) [22], 2012, the nation's air quality standards for $\mathrm{PM}_{2.5}$ is $35 \mu \mathrm{g} / \mathrm{m}^{3}$. The concentration of $\mathrm{PM}_{2.5}$ of the three cities during the study period ranged from $13.20 \mu \mathrm{g} / \mathrm{m}^{3}$ to $4315.64 \mu \mathrm{g} / \mathrm{m}^{3}$, which was classified as second-degree to sixth-degree pollution.

We retrieved gene expression profiles of the peripheral blood mononuclear cells (PBMC) from the enrolled subjects. In order to control for the clonal heterogeneity of PBMC as well as other confounding factors in the transcriptome, we decomposed the expression matrix using a weighted clustering algorithm and yielded 18 co-

Table 1 Summary of the subjects enrolled in the PBMC expression profiling study

\begin{tabular}{|c|c|c|c|c|c|}
\hline \multirow[t]{2}{*}{ City } & \multicolumn{2}{|l|}{ Gender } & \multicolumn{3}{|c|}{ Age (year) } \\
\hline & Female & Male & Median & Min & Max \\
\hline BeiJing & $15(62.50 \%)$ & 9 (37.50\%) & 29.5 & 23 & 48 \\
\hline TaiYuan & $42(80.77 \%)$ & 10 (19.23\%) & 32 & 19 & 82 \\
\hline ShiJiaZhuang & 35 (36.84\%) & $60(63.16 \%)$ & 43 & 21 & 80 \\
\hline
\end{tabular}

expressed gene modules (Fig. 1c) [18]. Each module represents a unique biological process corresponding to specific cell types or exposure factors. Then we evaluated the association between each co-expressed gene module and the exposure levels of the five pollutants (Fig. 1d). As a result, the pollutants are separated into two different groups based on the response patterns of the gene modules. $\mathrm{PM}_{2.5}, \mathrm{PM}_{10}$ and $\mathrm{SO}_{2}$ cause very similar effects in gene expression, which differ from those of $\mathrm{CO}$ and $\mathrm{NO}_{2}$. In particular, we noticed two gene modules ("cyan" and "brown") which are strongly associated with high exposure level of PM $\left(\mathrm{PM}_{10}\right.$ and $\mathrm{PM}_{2.5}, \mathrm{PCC}>$ 0.7 , Fig. 1c); and another two modules ("blue" and "turquoise") strongly associated with low exposure level (PCC $<-0.7$, Fig. 1c). As $\mathrm{PM}_{2.5}$ and $\mathrm{PM}_{10}$ cause similar effects in the transcriptome, we therefore refer both to "PM exposure" in the following analyses.

To reveal the biological background of the co-expressed modules strongly correlated with PM exposure, we annotated the modules for enriched KEGG pathways (Table 2 and Additional datasets: Data S1 and Fig. 1e). As a result, 
Table 2 Transcription factors (TF) underlying the co-expressed gene modules correlated with PM exposure ("cyan", "brown", "blue" and "turquoise"). TFs of which the binding motifs are significantly overrepresented in the co-expressed gene modules (FDR $<0.1$ ); or the target genes are overrepresented in the eigen genes of each module (q-value $<0.05$ ) are listed along with the KEGG pathways enriched (FDR < 0.05) in each module

\begin{tabular}{|c|c|c|c|}
\hline $\begin{array}{l}\text { Co- } \\
\text { expressed } \\
\text { Modules } \\
\end{array}$ & $\begin{array}{l}\text { Binding motifs enriched in } \\
\text { upregulated genes }\end{array}$ & Transcription factor activities & KEGG Pathway enrichment \\
\hline cyan & $\begin{array}{l}\text { Nrf2(bZIP); NFkB-p65(RHD); n-Myc } \\
\text { (bHLH); PIF4(bHLH); RAR:RXR (NR); IRF } \\
\text { (bZIP,IRF)/Th17-BatF }\end{array}$ & $\begin{array}{l}\text { NFKB1, RELA, JUN, NFIC, CEBPB, REL, CEBPD, SP1, } \\
\text { CTNNB1, CDX1, STAT1, DLX1, STAT6, RELB, } \\
\text { STAT3, DLX2, CEBPG, BCL6, PDX1, TFAP2A, } \\
\text { STAT2, GATA4, JUNB, GATA1, JUND, CREB1, YY1, } \\
\text { FOS, LEF1 }\end{array}$ & $\begin{array}{l}\text { Viral protein interaction with cytokine and } \\
\text { cytokine receptor; IL-17 signaling pathway; } \\
\text { Chemokine signaling pathway; Cytokine- } \\
\text { cytokine receptor interaction; Salmonella } \\
\text { infection; Rheumatoid arthritis; TNF signaling } \\
\text { pathway; Fluid shear stress and atherosclerosis; } \\
\text { Tuberculosis; NF-kappa B signaling pathway; } \\
\text { AGE-RAGE signaling pathway in diabetic } \\
\text { complications }\end{array}$ \\
\hline brown & $\begin{array}{l}\text { HOXA2(Homeobox); } \\
\text { Hoxb4(Homeobox); STAT4(Stat); } \\
\text { Pax7(Paired,Homeobox); E2A(bHLH); } \\
\text { Stat3(Stat); STAT6(Stat) }\end{array}$ & MYC, SP1, TP53, STAT1, CEBPA, STAT3, HOXD3 & $\begin{array}{l}\text { PD-L1 expression and PD-1 checkpoint } \\
\text { pathway in cancer }\end{array}$ \\
\hline blue & $\begin{array}{l}\text { FOXP1(Forkhead); Fli1(ETS); GABPA } \\
\text { (ETS); GATA3(Zf);RUNX-AML (Runt); } \\
\text { E2A(bHLH); ox2(HMG); ETS1(ETS); } \\
\text { Eomes(T-box) }\end{array}$ & $\begin{array}{l}\text { MYC, TFAP2A, SP1, ETS1, SPI1, GLI2, USF1, SP2, } \\
\text { RELA, SP3, ELK1, POU2F2, REL, STAT3, POU1F1, } \\
\text { ETV4, RELB, FOXO3, NFKB1, USF2, RUNX1, } \\
\text { FOXO1, E2F1, CTNNB1, MYB, E2F6, MYBL2, RARA, } \\
\text { GLI1, PPARD, JUN, RARG, PAX6, NFYA, TP53 }\end{array}$ & $\begin{array}{l}\text { Viral protein interaction with cytokine and } \\
\text { cytokine receptor; ErbB signaling pathway; } \\
\text { Epithelial cell signaling in Helicobacter pylori } \\
\text { infection }\end{array}$ \\
\hline turquoise & $\begin{array}{l}\text { Fli1(ETS), ETS1(ETS); ELF1(ETS); } \\
\text { Etv2(ETS); EABPA (ETS); Ets1-distal } \\
\text { (ETS); RUNX (ETS,Runt) }\end{array}$ & $\begin{array}{l}\text { CREB1, RBPJ, SP1, MYC, ATF1, CREBBP, SPI1, } \\
\text { NFKB1, RELA, SREBF2, SREBF1, TP53, ETV4, E2F1, } \\
\text { EGR1, FOXO1, NOTCH1, TFAP2A, YY1, BRCA1, } \\
\text { BCL3, ETS1, TCF7L2, USF2, ATF6, JUN, STAT3, } \\
\text { ESR1, CREM, PPARA, SMAD1, E2F6, FOXO3, } \\
\text { PPARG, WT1, NFATC2, FLI1, RFX1, EGR4, OLIG1, } \\
\text { FOXP1, CEBPB, PPARD, CTNNB1, ELK1, STAT5B, } \\
\text { IRF9, STAT5A, ATF2, NFYA, GLI2, AR, USF1, } \\
\text { STAT1, RELB, ID1, MYBL1, POU2F2, SMAD3, } \\
\text { SMAD2, E2F4, ERG, FOXH1, CEBPA, REL, NFIC, } \\
\text { ARNT, FEV, POU1F1, SP3, HOXA5, CEBPE, RARB, } \\
\text { FOXO4, MYB, NFIA, NFATC1, SOX10, RARA, } \\
\text { NR2F2, MITF, GABPA, HBP1, RARG, STAT2, } \\
\text { SMAD4, HIF1A, NR1H2, NR1H3, TCF7, RUNX2, } \\
\text { ATF4, NFE2L2, TBP, HNF4A, JUNB, NR2F1, CEBPD, } \\
\text { GLI1, GATA1 }\end{array}$ & $\begin{array}{l}\text { Lysine degradation; RNA degradation; N-Glycan } \\
\text { biosynthesis; Ubiquitin mediated proteolysis; } \\
\text { Valine, leucine and isoleucine degradation; } \\
\text { Spliceosome; RNA transport; Hepatitis C; } \\
\text { Propanoate metabolism; Cytosolic } \\
\text { DNA-sensing pathway }\end{array}$ \\
\hline
\end{tabular}

the module "cyan" significantly over represent the IL-17 signaling pathways (FDR $=0.000644)$; Cytokine-cytokine receptor interaction $(\mathrm{FDR}=0.00114)$. The module "brown" instead, enriches for PD-L1 expression and PD-1 checkpoint pathway in cancer $(\mathrm{FDR}=0.000397)$.

\section{Transcription factors mediate the inflammatory responses to PM exposure}

Next, we seek to identify the transcription factors (TFs) that regulate the co-expression of genes in response to PM exposure. As the change in the expression levels of the TF is difficult to detect, we first assessed the transcription factor activities based on the enrichment of the corresponding target genes present in each coexpression modules (Table 2, and Additional datasets: Data S3) [19]. From the modules positively correlated with PM exposure, we retrieved we retrieved 29 ("cyan") and 7 ("brown") TFs of which the target mRNAs are significantly enriched $(\mathrm{FDR}<0.1)$, including NFKB1 ("cyan", FDR =0.00128), MYC ("brown", FDR = 0.00147), STAT3 ("cyan", FDR $=0.0192$ ) etc. From the modules negatively correlated with PM exposure, we retrieved 35 ("blue") and 100 ("turquoise") significant TFs, including MYC ("blue", FDR =0.0008621), CREB1 ("turquoise", $\mathrm{FDR}=0.0004673), \quad \mathrm{SP} 1 \quad$ ("turquoise”, FDR =0.001402), ETS1 ("blue", FDR =0.003448; "turquoise", FDR = 0.01028 ), RUNX (“blue”, FDR $=0.081$ ) and so on.

To further reveal the transcription factors underlying the co-expressed modules, we resort to the DNAbinding-motifs which are bounded by known TFs and previously annotated in specific cell types [23]. For each module, we divide the member genes into two subsets, the "upregulated set" and the "down-regulated set". We evaluated the enrichment of 388 TF-binding motifs in the DNase I hypersensitivity sites (DHS) in the poised cis-regulatory regions (Additional datasets: Data S2) of either set of genes (Additional datasets: Data S4). As a result, we identified several enriched DNA motifs from 
the co-expressed genes significantly correlated with PM exposure, which are bounded by specific transcription factors (q-value $<0.1$, Tale 2). After removal of cell types that are not related to PBMC, we noticed several transcription factors that modulate the differentiation of $\mathrm{T}$ cells. For example, the upregulated set of the module "cyan" overrepresents NRF2 motif (q-value $=0.0174)$ and IRF4/BATF co-localization motif (q-value $=0.0534$ ); the upregulated set of the module "brown" overrepresents STAT3 $\quad(\mathrm{q}$-value $=0.0901), \quad$ STAT4 $\quad(q$-value $=0.0408)$ and STAT6 (q-value $=0.0903$ ); the upregulated set of the module "blue" overrepresents FLI1 (q-value $=0.0215$ ) and GATA3 (q-value =0.0673). On the other hand, we find no known binding motifs enriched in the "downregulated sets" of any co-expressed gene modules.

We compared the results of TF enrichment to the enrichment of pathways in the modules. As a result, we noticed six relevant transcription factors, which are likely regulating the co-expression in response to PM exposure. NFKB1 is enriched in module "cyan" for binding motif, target transcripts as well as the corresponding pathway. In the same module, we noticed another TF, IRF4 (with its binding partner BATF), of which the binding motif and the corresponding pathway (IL-17 signaling) are both significantly enriched. In module "brown", we found that the binding motif and the target transcript of STAT3 are also significantly enriched. Finally, transcription factors FLI1, ETS1 and RUNX are enriched in module "blue" and module "turquoise" for both binding motif and the target genes. Among the six transcription factors, FLI1, ETS1 and RUNX are overrepresent in both modules that are negatively associated with PM exposure, hence the function is suppressed and are less likely to be the effector. On the other hand, although NFKB1 enrichment is associated with high PM exposure, it is known as a general regulator of inflammation and widely reported for its role in diverse immune responses [24-26]. Therefore, we figure that IRF4 and STAT3 are the likely effectors of PM exposure and focus on the two genes in the following function validations. STAT3 is reported as effectors of PM exposure by previous studies [12, 27-29], and both TFs are known regulators of T-cells [30-38].

\section{Exposure to PM influences T-cell polarization in vitro}

The transcription factors enriched in the correlated coexpressed gene modules strongly suggests that PM exposure can influence the differentiation of T-cells. We then set out to further verify the effects of PM on T-cell differentiation.

Before the functional analysis, we analyzed the physical and chemical characteristics of the PM samples used for functional analysis. As for the chemical compositions, the major organic compositions of the particulate matters are organic carbon $(\mathrm{OC})$ and $\mathrm{SO}_{4}{ }^{2-}$. The major metals are
$\mathrm{Ca}, \mathrm{Fe}, \mathrm{Al}, \mathrm{Mg}, \mathrm{K}$ (Table S2). The average proportion of $\mathrm{PM}_{2.5}$ and $\mathrm{PM}_{10}$ in the PM sample is 0.75 (95\%CI: 0.700.80 ) and 0.22 (95\%CI: 0.17-0.28), respectively (Fig. S2A, B). Although prior study show that protease activity contributes to the immunogenicity of PM by induction of Th2 responses [39], there is no significant protease activity (1.08-fold of the blank control) in the PM samples we used at a concentration of $10 \mathrm{mg} / \mathrm{ml}$ (Fig. S2C).

We treated mouse-derived naive CD4+ T-cells with PM suspension and observed significantly increased polarization of T-helper cell type 2 (Th2, 77.04\%, $P=$ 0.00690), type 1 (Th1, $13.52 \%, P=0.0580$ ), and type 17 (Th17, 6.02\%, $P=0.0926$ ). On the other hand, the polarization of regulatory $\mathrm{T}$-cells ( $\mathrm{T}$-reg) in the naive CD4+ T-cells decreases with PM treatment (16.67\%, $P=$ 0.0130) (Fig. 2).

We further assessed the expression levels of the transcription factors of which the binding motifs are overrepresented in the co-expressed gene modules positively correlated with PM exposure. As a result, the expression levels of Stat3, Irf4 and Batf significantly increase with PM treatment $(P<0.05$, Fig. 2c).

The change in the expression levels of Stat 3 and Irf4/ Batf are consistent to the altered $\mathrm{T}$-cell polarization in naïve CD4+ T-cells. Together we hypothesize that Stat3 and Irf4/Batf are the potential effectors of PM exposure and modulators of consequential $\mathrm{T}$-cell polarization.

\section{Exposure to PM influences T-cell polarization in vivo}

To ascertain the impacts of PM exposure on T-cell polarization in vivo, we treated healthy mice $(\mathrm{BALB} / \mathrm{c})$ with PM suspension intranasally (Fig. 3a). In mouse lung treated with PM, we observed infiltration of neutrophils and lymphocytes into the terminal bronchiole and small vessels (Fig. 3b), which correspond to significantly increased inflammation score $(P=0.0006$, Fig. 3c). Such pathological changes are similar to the inflammatory responses in allergic respiratory diseases such as asthma. In the bronchoalveolar lavage fluid, we observed consistent increase in the number of neutrophils, lymphocytes and macrophages $(P<0.05)$ but not eosinophils (Fig. 3d, e).

Then we assessed the polarization of Th1, Th2, Th17 and Treg in mouse lung at different time points following the treatment of PM suspension (Fig. 4a, see Additional file 1: Figure S3). At $18 \mathrm{~h}$, we observed significantly elevated Th17 activities $(70.87 \%, P=0.0367)$; followed by increased activities of Th1 and Th2 (143.57\%, $P=0.0069$ for Th1 and $81.55 \%, P=0.0228$ for Th2) at the $24 \mathrm{~h}$. Finally, at $72 \mathrm{~h}$ we noticed a significant Treg response and a restoration of Th17. We also assessed the balance between Th1/Th2 and Treg/Th17, respectively (Fig. 4b). As a result, Th1/Th2 balance remains relatively stable throughout $72 \mathrm{~h}$. Treg/Th17 ratio drops to 0.532 at $18 \mathrm{~h}(P=0.0221)$ then mount to 8.651 at the $24 \mathrm{~h}(P=0.0442)$. The fluctuation in Treg/ 


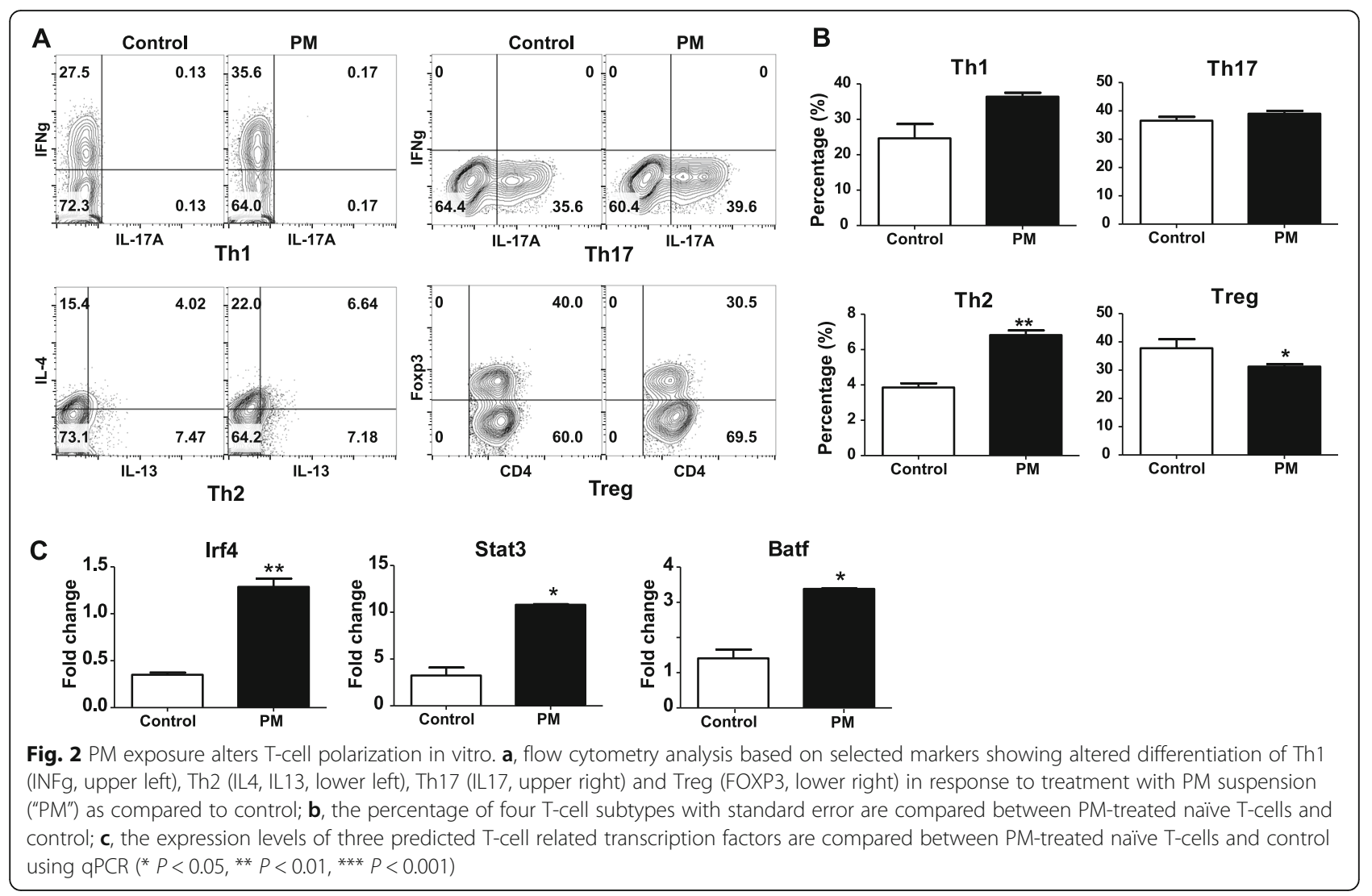

Th17 balance is mainly driven by the fast changing Th17 activities in the first $24 \mathrm{~h}$ following the treatment, which also causes of the pathological changes in the airway.

Consistent to the changes in T-cell polarization, the expression levels of Stat3 $(P=0.0286)$, Irf4 $(P=0.0038)$ and Batf $(P=0.0002)$ are also significantly higher in the mouse lung following the treatment of PM suspension (Fig. 5a). We further assessed the expression levels of the related interleukins in the bronchoalveolar lavage fluid (BALF, Fig. 5b). As a result, the expression levels of IL17A $(P=0.0079)$ is elevated in following the treatment with PM suspension. The other two interleukins related to Th17, IL21 and IL22 however show no significant change. As for Th2 related interleukins in PM-treated group, we observed a significant increase of IL4 ( $P=$ 0.0268) in lung tissue, but no significant change of IL4 and IL13 levels in the BALF (Fig. 5b). Finally, in the mouse serum, we did not observe significant changes in the cytokine levels that relate to the T-cell subtypes aforementioned (see Additional file 1: Figure S4).

\section{Stat3 and Irf4 signaling is involved in the Th2 and Th17 differentiation induced by PM}

Base on both in vitro and in vivo evidence, we figure that Stat3, Irf4 are potential effectors of PM exposure and directly involved in the altered $\mathrm{T}$-cell polarization.
Therefore, we moved on to verify that Stat3 and Irf4 functions in response to PM exposure at the protein level. Stat3 and Irf4 are both known transcription factors promoting Th2/Th17 polarization $[40,41]$. We measured the protein levels of the activated form of Stat3 (phosphorylated-Stat3) and Irf4 (phosphorylated-Irf4) in the lung tissue following the treatment of PM suspension. As a result, phosphorylated Stat3 significantly increases in the lung tissues of mice $24 \mathrm{~h}$ following the treatment $(612.03 \%, P<0.001)$. And phosphorylated Irf4 levels also show significant elevation following the treatment of PM suspension (29.92\%, $P=0.0294$ ) (Fig. 6). These results, together, suggest that Irf4 and Stat3 are the main effectors of PM exposure thus modulate the immunogenicity of particulate matters in the respiratory tracts.

\section{Discussion}

The hazardous effects of particulate matters on human health have been proved by prior studies from two aspects. First, populational studies evaluate the health effects from long-term survey confirm that exposure to PM is associated with diverse diseases. Then empirical studies use cell lines or animals to validate the acute effects of PM. Many of these studies suggest that the toxicity of PM is related to the immunogenicity [42], but 


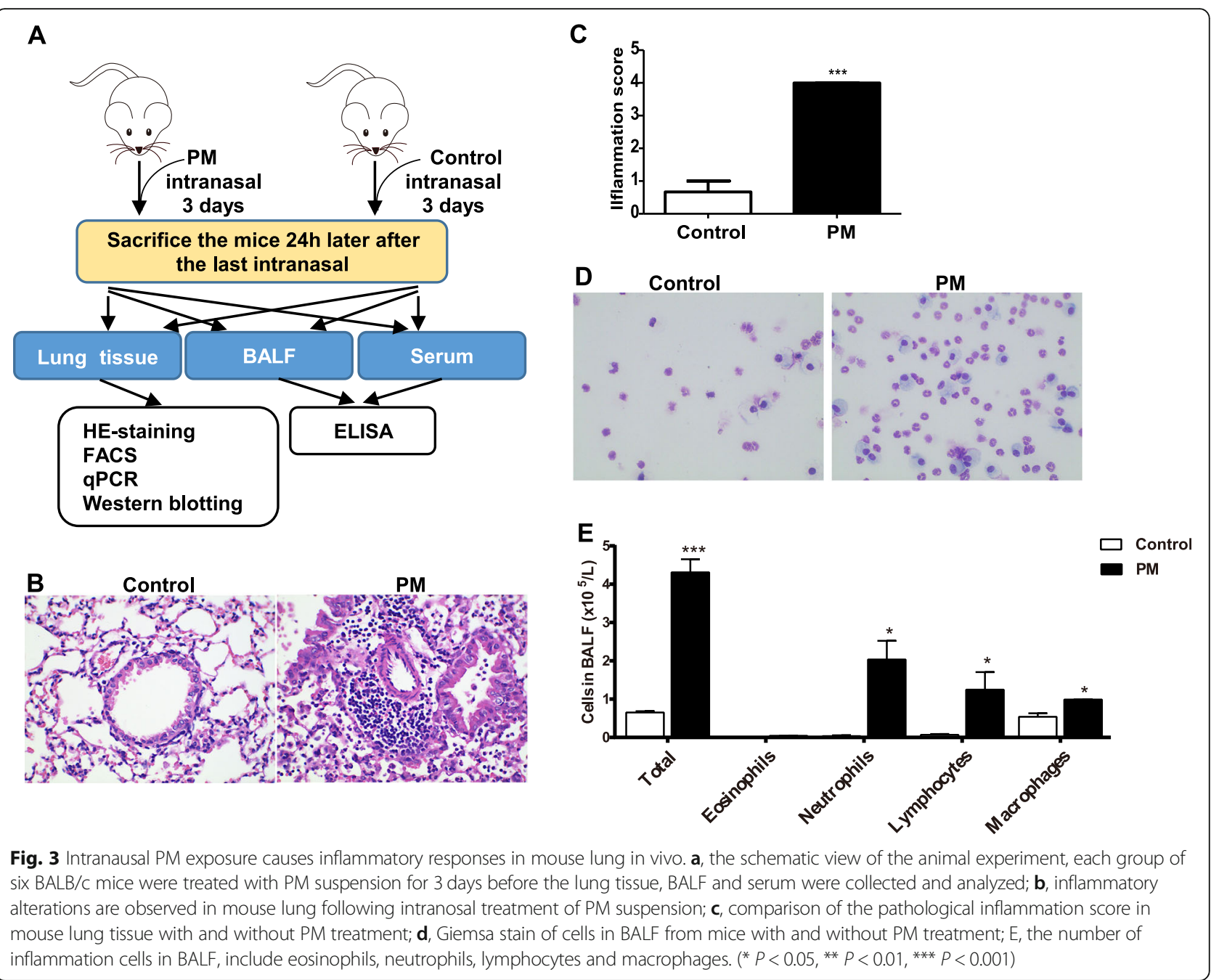

few verified the biological mechanism in human subjects [43]. Here we conducted peripheral blood gene expression profiling in a healthy population in northern China. Our data shows that exposure to PM causes systematic effects in the transcriptome and we identified sets of co-expressed genes which strongly correlate with the level of exposure.

We then described a method integrating multi-level information to infer the transcription regulators driving the co-expressed gene modules strongly associated with PM. We report three transcription factors as effectors of PM exposure: NFkB and STAT3 are previously reported by in vitro analysis [44, 45]; IRF4, however, is reported for the first time to regulate in the immune responses to PM. IRF4 is known as a regulator of T-cell differentiation which is activated by NFkB, NFAT and TLR4 signaling [46-51]. Plus, IRF4 is involved in various inflammatory responses to microbial pathogens such as muramyl dipeptide (MDP) or lipopolysaccharide (LPS). Whether IRF4 is activated by PM through the same signaling modules still remain to be elucidated.
Our analyses demonstrate that the activation of Stat3 and Irf4 are associated with Treg/Th17 imbalance in response to PM treatment. The imbalance of Th17 and Treg is implicated in many allergic diseases in respiratory system [52, 53]. Especially, Th17 mediated inflammatory responses are crucial for the onset, exacerbation and control of Asthma and Chronic Obstructive Pulmonary Disease [54-59]. The role of STAT3 in Treg/Th17 imbalance in widely reported for allergic diseases. STAT3 activate Th17 upon IL-6 and IL-23R signaling and degrade by ubiquitination [60-62]. STAT3 is a known effector of PM [63-65]; IRF4 is also known for its function in Asthma by activating Th17 through regulation of chromatin accessibility but not for the role in response to PM exposure [66, 67]. Together our data suggest a potential risk of PM exposure to allergic respiratory diseases and regulators of Th17/Treg imbalance are likely effectors of PM.

There are other T-cell subtypes are also associated with the inflammatory responses to PM but lack of consistent evidences from in vitro validation in our data. For 

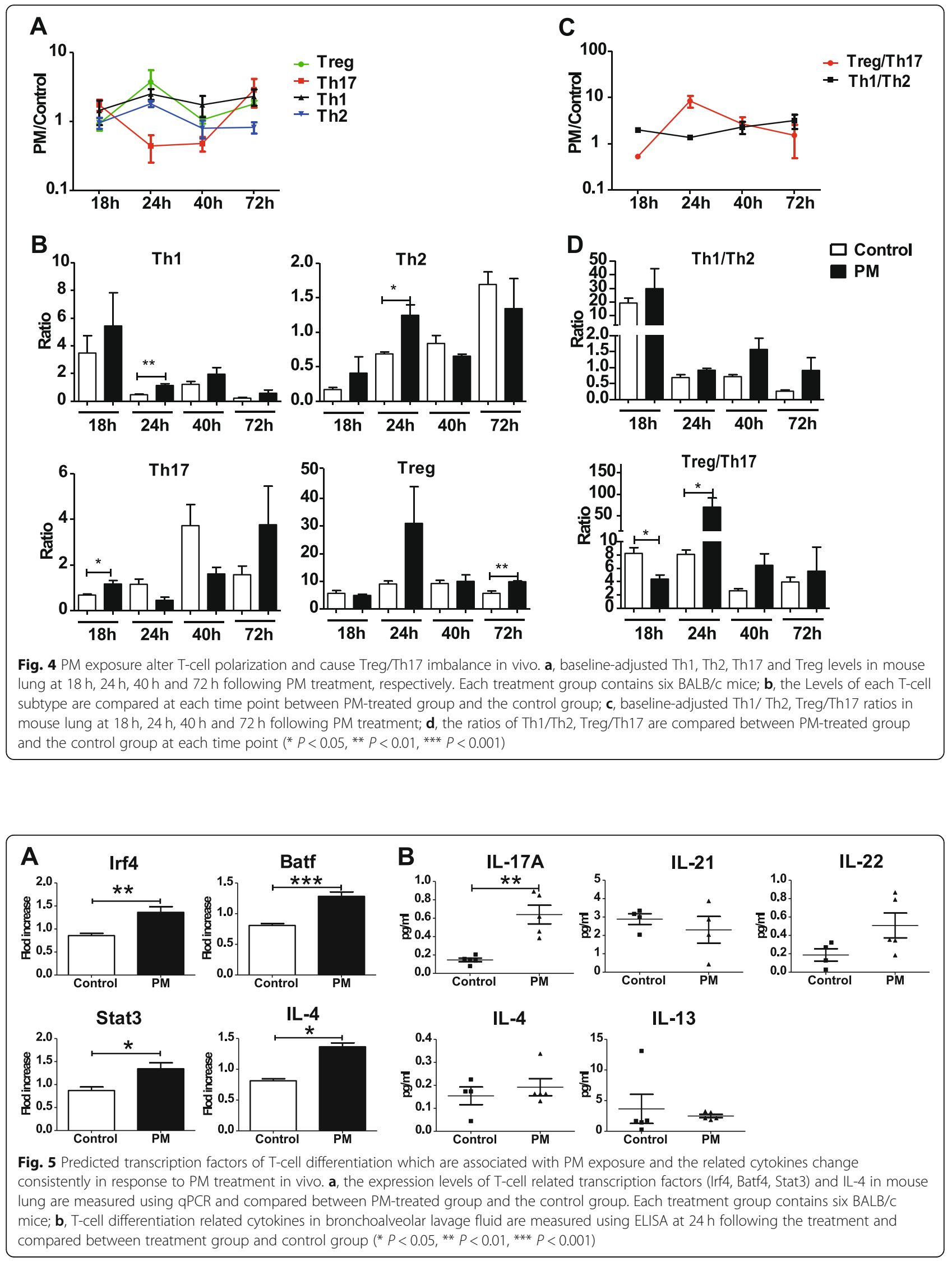


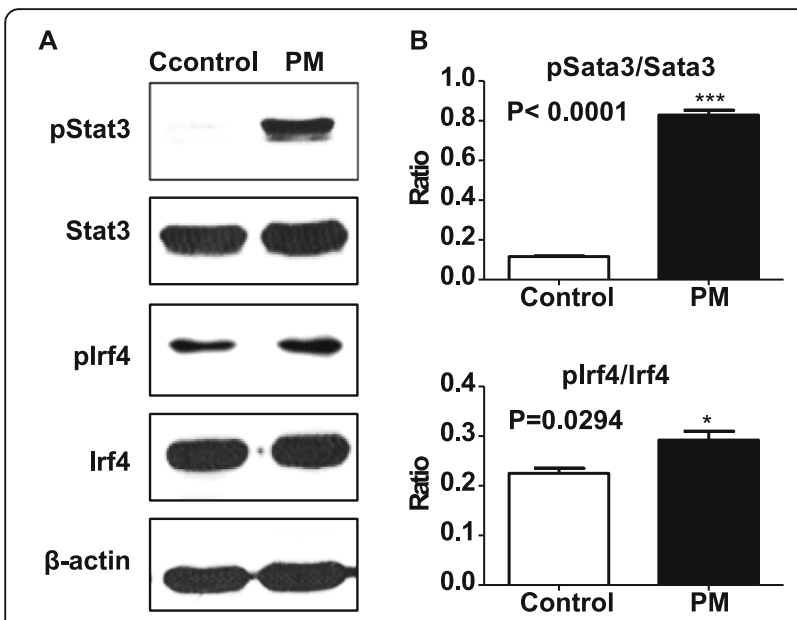

Fig. 6 The levels of phosphorylated Stat3 and Irf4 increases in mice lung tissues in response to PM exposure in vivo. Two groups of six BALB/C mice were treated with PM suspension for 3 days then after $24 \mathrm{~h}$ the lung tissue were collected for Western Blot assay. a, Western Blot showing the protein expression levels of phosphorylate-Stat3 (pStat3), un-phosphoStat3 (Stat3), phosphorylate-IIf4 (plif4), un-phospho-IIf4 (IIf4) with betaactin as control; b, the ratios of phosphorylate-Stat3 versus un-phosphoStat3 and phosphorylate-Iff4 versus un-phospho-Irf4 increase significantly in response to PM treatment $\left({ }^{*} P<0.05,{ }^{* *} P<0.01\right.$, $\left.{ }^{* *} P<0.001\right)$

example, Treg activity decrease after $48 \mathrm{~h}$ in response to PM treatment in primary $\mathrm{T}$ cell culture but show no significant change in mice. Such inconsistent observations are attributed to the difference of in vitro and in vivo analysis, as the latter is influenced by more complexed effects and is more likely to represent the real biological activity. In addition, our data demonstrate the timecourse of $\mathrm{T}$-cell responses following the exposure to $\mathrm{PM}$, which suggest the $\mathrm{T}$ cell responses reaches a steady state through an interactive process.

Quantification of the exposure level of PM in a realworld cohort is subject to various confounding effects from environmental to behavioral factors. In this study, we use three-week average concentration of the PM. As prior epidemiological studies observed the strongest effects of PM exposure between 5 to 21 days [68]. Moreover, many in vitro studies reveal the full effects of PM exposure on T-cell differentiation in a course of 2-3 weeks [69]. finally, a three-week lag also minimizes possible carry-over effects from previous exposure [70].

The expression profiles from PBMC consist transcripts from multiple cell types. Here we performed conformity-based decomposition of the expression profile to account for the latent heterogeneity and retrieved gene modules representing specific biological processes. While our studies predicted and validated some of the major effectors of PM exposure, there may be other effectors yet to be discovered from larger cohort.

The current study does not address the variations of the physical-chemical properties in the PMs from different sources, which eventually influence the immunogenicity of PM. The PM samples used in this study are mostly originated from combustion of fossil and biomass fuels. Some molecules such as the heavy metals, polycyclic aromatic hydrocarbons are absorbed by the particles and cause immune responses [71]. Protease activity is known to induce Th2 responses but doesn't present in the samples we used. This can be caused by the sample collection and preparation. On the other hand, it also suggests that other factors contribute to the immunogenicity of the PM.

Finally, the roles of the T-cell regulators in response to PM need to be validated empirically in animal models with deficient STAT3 and IRF4. The current study highlights STAT3 and IRF4 as possible effectors of PM exposure and inform future functional analyses to reveal the biological and pathological background of PM caused respiratory allergy.

\section{Conclusions}

In summary, we demonstrate the transcriptional effects of PM exposure in a healthy population and verified the corresponding regulatory activities of IRF4 and STAT3 using cell and animal models, which further inform the molecular basis of the immunogenicity and pathogenicity of PM. In addition, our results provide useful clues to clinical management for PM-associated allergic respiratory diseases.

\section{Supplementary information}

Supplementary information accompanies this paper at https://doi.org/10. 1186/s12931-020-01368-2.

Additional file 1: Reagents and Antibodies. Table S1. Primer sequences for qRT-PCR analyses. We designed all the primers using https://sg.idtdna.com/ pages/products/Custom-dna-rna combine with the NCBI and UCSC websites. Table S2. Chemical characteristics of the PM samples used for functional analyses. Water soluble ions were analyzed by ion chromatography, element measurement by inductivity coupled plasma-mass spectrometry (ICP-MS); and organic carbon (OC) and elemental carbon (EC) fractions by DRI model 2001 carbon analyzer. Figure S1. The average concentration of $\mathrm{PM}_{2.5}$ and $\mathrm{PM}_{10}$ in the three Chinese cities (Beijing, Taiyuan, Shijiazhuang) during the study period. We collected environmental data of 3 weeks preceding the sampling. The actual time period of sampling in the three cities: 10/04/2014-26/04/2014 in Shijiazhuang, Taiyuan: 21/02/2014-01/05/2014 and Beijing: 26/09/2014-16/ 10/2014. Figure S2. Size distribution and protease activity of the PM sample. A. $20 \times$ microscopic view of PM suspension showing the distribution of $\mathrm{PM}_{2.5}$ and $\mathrm{PM}_{10} ; \mathrm{B}$. protease activity of the PM samples based on FITC-labeled casein cleavage hydrolysis assay. The protease activities are measured by mean fluorescence level with standard deviation. Figure S3. Expression levels of T-cell related cytokines in mouse serum follow the treatment of PM. Figure S4.

Differentiation statuses of T-cell subtypes in mouse lung following the treatment of PM suspension. T-cell differentiation is evaluated by flow cytometry at $18 \mathrm{~h}, 24 \mathrm{~h}, 40 \mathrm{~h}$ and $72 \mathrm{~h}$ after the treatment.

Additional file 2: Sheet data S1. Gene list of the 18 co-expressed gene modules identified from the PBMC profiling study. Sheet data S2. KEGG pathways and GO biological processes significantly enriched in the coexpressed gene modules. Sheet data S3. Enrichment of the target genes of known transcription factors in the four modules strongly correlated with PM exposure. Sheet data S4. Enrichment of the binding motifs of known transcription factors in the poised cis-regulatory regions of the genes of the four modules strongly correlated with PM exposure. 


\section{Abbreviations}

PM: Particulate matter; COPD: Chronic obstructive pulmonary disease; AD: Atopic dermatitis; TF: Transcription factors; UFP: Ultra-fine particles; DHS: DNasel hypersensitivity sites; TSS: Transcription starting sites; CMC: Carboxymethylcellulose; XMULAC: Xiamen University Laboratory Animal Center; WGCNA: Weighted gene co-expression network analysis; BALF: Bronchoalveolar lavage fluid; MDP: Muramyl dipeptide; LPS: Lipopolysaccharide; PBMCs: Peripheral blood mononuclear cells; SPF: Specific pathogen-free

\section{Acknowledgements}

We thank Dr. Zhan, Liyang and Dr. Zhou, Linfu for help with the collection of ambient PM, and Dr. Yan, Jinpei for the advices on this article.

\section{Authors' contributions}

QL, JW and ZL designed the experiments; DG performed the experiments; $H Q$, CW, ZL collected patient data; LH, ZC, XL, SW and CL provided help for the experiments; $T Z, Y Z$ and $K L$ analyzed the data; $Q L, D G$ and $Y Z$ wrote the manuscript; $Y Z$ and $Z L$ offered help the bioinformatic analysis. The author(s) read and approved the final manuscript.

\section{Funding}

This work was supported by the Natural Science Foundation of Fujian Province (No. 2016 J01644), National Natural Science Foundation of China (No. 31371289), and Science and Technology Bureau of Xiamen (NO. 3502Z20189013).

\section{Availability of data and materials}

The datasets generated and analysed during the current study are available from the correspondence author on reasonable request.

\section{Ethics approval and consent to participate}

The animal experiment was approved by the Institutional Animal Care and Use Committee (Laboratory animal license: SYXK (Min) 2018-0010) and was in accordance with good animal practice as defined by the XMULAC (Xiamen Univerisity Laboratory Animal Center).

\section{Consent for publication}

\section{Not applicable.}

\section{Competing interests}

The authors declare that they have no competing interests.

\section{Author details}

'Department of Pediatrics, the First Affiliated Hospital of Xiamen University, Xiamen 361003, China. ${ }^{2}$ Maternal and Child Health Hospital Affiliated Xiamen University, Xiamen 361102 , China. ${ }^{3}$ Pediatric Key Laboratory of Xiamen, Xiamen 361003, China. ${ }^{4}$ Medical Research Institute of Children, School of Medicine, Xiamen University, the First Affiliated Hospital of Xiamen University, Xiamen 361003, China. ${ }^{5}$ National Institute of Data Science in Health and Medicine, School of Medicine, Xiamen University, Xiamen 361102, China. ${ }^{6}$ Experimental Immunology Branch, National Cancer Institute, $\mathrm{NIH}$, Bethesda, MD, USA. ${ }^{7}$ Department of Ophthalmology and Vision Science, Eye \& ENT Hospital, Fudan University, Shanghai 200032, China. ${ }^{8}$ Shanghai Key Laboratory of Visual Impairment and Restoration, Shanghai 200032, China. ${ }^{9} \mathrm{NHC}$ Key Laboratory of Myopia, Fudan University, Shanghai 200032, China. ${ }^{10}$ The 980st Hospital of the PLA Joint Logistics Support Force (Primary Bethune International Peace Hospital of PLA), Shijiazhuang, Hebei 050082, China. ${ }^{11}$ Fujian Provincial Key Laboratory of Ophthalmology and Visual Science, Eye Institute of Xiamen University, School of Medicine, Xiamen University, Xiamen 361102, China. ${ }^{12}$ Marine Chemistry and Toxicology Research Center, College of the Environment \& Ecology, Xiamen University, Xiamen 361102, China.

\section{Received: 9 October 2019 Accepted: 22 April 2020}

Published online: 24 May 2020

\section{References}

1. Naghavi MWH, Lozano R, Davis A, Liang X. Global, regional, and national age-sex specific all-cause and cause-specific mortality for 240 causes of death, 1990-2013: a systematic analysis for the global burden of disease Study 2013. Lancet. 2015;385:117-71.
2. Krishnan RM, Adar SD, Szpiro AA, Jorgensen NW, Hee VCV, Barr RG, O'Neill MS, Herrington DM, Polak JF, Kaufman JD. Vascular responses to long- and short-term exposure to fine particulate matter : MESA air (multi-ethnic Study of atherosclerosis and air pollution). J Am Coll Cardiol. 2016;60:2158-66.

3. Owens EO, Knuckles TL, Campen MJ. Air pollution and cardiovascular disease. Compr Toxicol. 2018;124:480-513.

4. Hamra GB, Guha N, Cohen A, Laden F, Raaschou-Nielsen O, Samet JM, Vineis $P$, Forastiere F, Saldiva P, Yorifuji T, Loomis D. Outdoor particulate matter exposure and lung cancer: a systematic review and meta-analysis. Environ Health Perspect. 2014;122:906-11.

5. Tomczak A, Miller AB, Weichenthal SA, To T, Wall C, Van DA, Martin RV, Crouse DL, Villeneuve PJ. Long-term exposure to fine particulate matter air pollution and the risk of lung cancer among participants of the Canadian National Breast Screening Study. Int J Cancer. 2016;139:1958-66.

6. Schikowski T, Mills IC, Anderson HR, Cohen A, Hansell A, Kauffmann F, Kramer U, Marcon A, Perez L, Sunyer J, et al. Ambient air pollution: a cause of COPD? Eur Respir J. 2014;43:250-63.

7. Ahn K. The role of air pollutants in atopic dermatitis. J Allergy Clin Immunol. 2014;134:993-9 discussion 1000.

8. Kim KE, Cho D, Park HJ. Air pollution and skin diseases: adverse effects of airborne particulate matter on various skin diseases. Life Sci. 2016;152:126-34.

9. Chen H, Burnett RT, Kwong JC, Villeneuve PJ, Goldberg MS, Brook RD, Van DA, Jerrett M, Martin RV, Kopp A. Spatial association between ambient fine particulate matter and incident hypertension. Circulation. 2014;129:562.

10. Esposito K, Petrizzo M, Maiorino MI, Bellastella G, Giugliano D. Particulate matter pollutants and risk of type 2 diabetes: a time for concern? Endocrine. 2015:51:1-6.

11. Li J, Tan G, Ding X, Wang Y, Wu A, Yang Q, Ye L, Shao Y. A mouse dry eye model induced by topical administration of the air pollutant particulate matter 10. Biomed Pharmacother. 2017;96:524-34.

12. Guo ZQ, Dong WY, Xu J, Hong ZC, Zhao RW, Deng CR, Zhuang GS, Zhang RX. T-helper type 1-T-helper type 2 shift and nasal remodeling after fine particulate matter exposure in a rat model of allergic rhinitis. Am J Rhinol Allergy. 2017;31:148-55.

13. Baldacci S, Maio S, Cerrai S, Sarno G, Baiz N, Simoni M, Annesi-Maesano I, Viegi G, Study H. Allergy and asthma: effects of the exposure to particulate matter and biological allergens. Respir Med. 2015;109:1089-104.

14. Kelly FJ, Fussell JC. Size, source and chemical composition as determinants of toxicity attributable to ambient particulate matter. Atmos Environ. 2012; 60:504-26.

15. Can Z, Jiping L, Weili C, Suxia W, Tongsheng Y, Yinghong T, Guangfa W. Involvement of TLR2 and TLR4 and Th1/Th2 shift in inflammatory responses induced by fine ambient particulate matter in mice. Inhal Toxicol. 2012;24: 918-27.

16. Deng X, Rui W, Zhang F, Ding W. PM2.5 induces Nrf2-mediated defense mechanisms against oxidative stress;by activating PIK3/AKT signaling pathway in human lung alveolar;epithelial A549 cells. Cell Biol Toxicol. 2013; 29:143-57.

17. Deng X, Fang Z, Wang L, Wei R, Fang L, Yong Z, Chen D, Ding W. Airborne fine particulate matter induces multiple cell death pathways in human lung epithelial cells. Apoptosis. 2014;19:1099-112.

18. Langfelder P, Horvath S. WGCNA: an R package for weighted correlation network analysis. Bmc Bioinformatics. 2008;9:559.

19. Essaghir A, Toffalini F, Knoops L, Kallin A, van Helden J, Demoulin JB. Transcription factor regulation can be accurately predicted from the presence of target gene signatures in microarray gene expression data. Nucleic Acids Res. 2010;38:e120.

20. Consortium TEP. The ENCODE (ENCyclopedia of DNA elements) project. Science. 2004;306:636-40.

21. Heinz S, Benner C, Spann N, Bertolino E, Lin YC, Laslo P, Cheng JX, Murre C, Singh $H$, Glass CK. Simple combinations of lineage-determining transcription factors prime cis-regulatory elements required for macrophage and B cell identities. Mol Cell. 2010;38:576-89.

22. EPA: Environment Protection Agency (EPA), National Ambient Air Quality Standards (NAAQS) for Particulate Matter. 2012, Available at https://www. epa.gov/pm-pollution/table-historical-particulate-matter-pm-nationalambient-air-quality-standards-naaqs\#Superscript8.

23. Small KS, Hedman AK, Elin G, Nica AC, Gudmar T, Augustine K, Unnur T, SoYoun S, Richards HB, Nicole S. Identification of an imprinted master trans regulator at the KLF14 locus related to multiple metabolic phenotypes. Nat Genet. 2011:43:561-4. 
24. Taniguchi K, Karin M. NF-kappaB, inflammation, immunity and cancer: coming of age. Nat Rev Immunol. 2018;18:309-24.

25. Sun SC. The non-canonical NF-kappaB pathway in immunity and inflammation. Nat Rev Immunol. 2017;17:545-58

26. Pasparakis M. Regulation of tissue homeostasis by NF-kappaB signalling: implications for inflammatory diseases. Nat Rev Immunol. 2009;9:778-88.

27. Chan RC, Wang M, Li N, Yanagawa Y, Onoe K, Lee JJ, Nel AE. Pro-oxidative diesel exhaust particle chemicals inhibit LPS-induced dendritic cell responses involved in T-helper differentiation. J Allergy Clin Immunol. 2006; 118:455-65.

28. Cohen PA, Koski GK, Czerniecki BJ, Bunting KD, Fu XY, Wang Z, Zhang WJ, Carter CS, Awad M, Distel CA. STAT3- and STAT5-dependent pathways competitively regulate the pan-differentiation of CD34pos cells into tumorcompetent dendritic cells. Blood. 2008;112:1832.

29. Cao D, Tal TL, Graves LM, Gilmour I, Linak W, Reed W, Bromberg PA, Samet JM. Diesel exhaust particulate-induced activation of Stat3 requires activities of EGFR and Src in airway epithelial cells. Am J Physiol Lung Cell Mol Physiol. 2007:292:422-9.

30. Brustle A, Heink S, Huber M, Rosenplanter C, Stadelmann C, Yu P, Arpaia E, Mak TW, Kamradt T, Lohoff M. The development of inflammatory $T(H)-17$ cells requires interferon-regulatory factor 4. Nat Immunol. 2007:8:958-66.

31. Huber M, Brustle A, Reinhard K, Guralnik A, Walter G, Mahiny A, von Low E, Lohoff M. IRF4 is essential for IL-21-mediated induction, amplification, and stabilization of the Th17 phenotype. Proc Natl Acad Sci U S A. 2008;105: 20846-51.

32. Wei L, Laurence A, Elias KM, O'Shea JJ. II-21 is produced by TH17 cells and drives IL-17 production in a STAT3-dependent manner. J Biol Chem. 2007; 282:34605-10.

33. Renner ED, Rylaarsdam S, Aňoversombke S, Rack AL, Reichenbach J, Carey JC, Zhu Q, Jansson AF, Barboza J, Schimke LF. Novel STAT3 mutations, reduced TH17 cell numbers, and variably defective STAT3 phosphorylation in hyper-lgE syndrome. J Allergy Clin Immunol. 2008;122:181.

34. Ma CS, Chew GYJ, Simpson N, Priyadarshi A, Wong M, Grimbacher B, Fulcher DA, Tangye SG, Cook MC. Deficiency of Th17 cells in hyper lgE syndrome due to mutations in STAT3. Jexpmed. 2008;205:1551-7.

35. Chaudhry A, Rudra D, Treuting P, Samstein RM, Liang Y, Kas A, Rudensky AY. CD4+ regulatory $\mathrm{T}$ cells control $\mathrm{TH} 17$ responses in a Stat3-dependent manner. Science. 2009;326:986-91.

36. Kim BS, Kim IK, Park YJ, Kim YS, Kim YJ, Chang WS, Lee YS, Kweon MN, Chung Y, Kang CY. Conversion of Th2 memory cells into Foxp3+ regulatory T cells suppressing Th2-mediated allergic asthma. Proc Natl Acad Sci U S A. 2010;107:8742-7.

37. Ye Z, Ashutosh C, Arnold K, Paul D, Kim JM, Tin-Tin C, Lynn C, Piper T, Ulf K, Rudensky AY. Regulatory T-cell suppressor program co-opts transcription factor IRF4 to control T(H)2 responses. Nature. 2009:458:351-6.

38. Lohoff M, Mittrücker HW, Prechtl S, Bischof S, Sommer F, Kock S, Ferrick DA, Duncan GS, Gessner A, Mak TW. Dysregulated T helper cell differentiation in the absence of interferon regulatory factor 4. Proc Natl Acad Sci U S A. 2002;99:11808-12

39. Oh JE, Oh DS, Jung HE, Lee HK. A mechanism for the induction of type 2 immune responses by a protease allergen in the genital tract. Proc Natl Acad Sci U S A. 2017;114:E1188-95.

40. Williams JW, Tjota MY, Clay BS, Vander Lugt B, Bandukwala HS, Hrusch $\mathrm{CL}$, Decker DC, Blaine KM, Fixsen BR, Singh $\mathrm{H}$, et al. Transcription factor IRF4 drives dendritic cells to promote Th2 differentiation. Nat Commun. 2013:4:2990.

41. Gavino AC, Nahmod K, Bharadwaj U, Makedonas G, Tweardy DJ. STAT3 inhibition prevents lung inflammation, remodeling, and accumulation of Th2 and Th17 cells in a murine asthma model. Allergy. 2016;71:1684-92.

42. Jaligama S, Chen Z, Saravia J, Yadav N, Lomnicki SM, Dugas TR, Cormier SA. Exposure to Deepwater horizon crude oil Burnoff particulate matter induces pulmonary inflammation and alters adaptive immune response. Environ Sci Technol. 2015:49:8769-76.

43. Li N, Fang H, Liao B, Zhou Y, Bing L, Ran P. Exposure to ambient particulate matter alters the microbial composition and induces immune changes in rat lung. Respir Res. 2017:18:143.

44. Reyes-Zarate E, Sanchez-Perez Y, Gutierrez-Ruiz MC, Chirino Yl, OsornioVargas AR, Morales-Barcenas R, Souza-Arroyo V, Garcia-Cuellar CM. Atmospheric particulate matter (PM10) exposure-induced cell cycle arrest and apoptosis evasion through STAT3 activation via PKCzeta and Src kinases in lung cells. Environ Pollut. 2016;214:646-56.
45. Li T, Zhao J, Ge J, Yang J, Song X, Cheng W, Mao J, Yan Z, Ye Z, Liu Y. Particulate matter facilitates C6 Glioma cells activation and the release of inflammatory factors through MAPK and JAK2/STAT3 pathways. Neurochem Res. 2016:41:1-13.

46. Winslow MM, Gallo EM, Neilson JR, Crabtree GR. The Calcineurin phosphatase complex modulates immunogenic B cell responses. Immunity. 2006;24:141-52

47. Ulf K, Stefano C, Giorgio C, Qiong S, Marie L, Tongwei M, Thomas L, Klaus R, Riccardo DF. Transcription factor IRF4 controls plasma cell differentiation and class-switch recombination. Nat Immunol. 2006;7:773-82.

48. Sciammas R, Shaffer AL, Schatz JH, Zhao H, Staudt LM, Singh H. Graded expression of interferon regulatory Factor-4 coordinates Isotype switching with plasma cell differentiation. Immunity. 2006;25:225-36.

49. Matsuyama T, Grossman A, Mittrücker HW, Siderovski DP, Kiefer F, Kawakami T, Richardson CD, Taniguchi T, Yoshinaga SK, Mak TW. Molecular cloning of LSIRF, a lymphoid-specific member of the interferon regulatory factor family that binds the interferon-stimulated response element (ISRE). Nucleic Acids Res. 1995;23:2127-36.

50. Gao J, Morrison DC, Parmely TJ, Russell SW, Murphy WJ. An interferon- $\gamma$ activated site (GAS) is necessary for full expression of the mouse iNOS gene in response to interferon- $y$ and lipopolysaccharide. J Exp Med. 2000;191: 1281-92.

51. Eisenbeis CF, Singh $H$, Storb U. Pip, a novel IRF family member, is a lymphoid-specific, PU.1-dependent transcriptional activator. Genes Dev. 1995;9:1377-87.

52. Brandenberger C, Li N, Jacksonhumbles DN, Rockwell CE, Wagner JG, Harkema JR. Enhanced allergic airway disease in old mice is associated with a Th17 response. Clin Exp Allergy. 2015;44:1282-92.

53. Imani S, Salimian J, Fu J, Ghanei M, Panahi Y. Th17/Treg-related cytokine imbalance in sulfur mustard exposed and stable chronic obstructive pulmonary (COPD) patients: correlation with disease activity. Immunopharmacol Immunotoxicol. 2016;38:270-80.

54. Zhang JH, Yang X, Chen YP, Zhang JF, Li CQ. Nrf2 activator RTA-408 protects against ozone-induced acute asthma exacerbation by suppressing ROS and gammadeltaT17 cells. Inflammation. 2019;42:1843-56.

55. Cui H, Huang J, Lu M, Zhang Q, Qin W, Zhao Y, Lu X, Zhang J, Xi Z, Li R. Antagonistic effect of vitamin $\mathrm{E}$ on nAl2O3-induced exacerbation of Th2 and Th17-mediated allergic asthma via oxidative stress. Environ Pollut. 2019; 252:1519-31.

56. Hirai K, Shirai T, Suzuki M, Akamatsu T, Suzuki T, Hayashi I, Yamamoto A, Akita T, Morita S, Asada K, et al. A clustering approach to identify and characterize the asthma and chronic obstructive pulmonary disease overlap phenotype. Clin Exp Allergy. 2017;47:1374-82.

57. Ye WJ, Xu WG, Guo XJ, Han FF, Peng J, Li XM, Guan WB, Yu LW, Sun JY, Cui $Z L$, et al. Differences in airway remodeling and airway inflammation among moderate-severe asthma clinical phenotypes. J Thorac Dis. 2017;9:2904-14.

58. Zhu R, Xie X, Wang N, Chen L, Hong Y. The T helper type 17/regulatory T cell imbalance was associated with Ras-GTPase overexpression in patients with pulmonary hypertension associated with chronic obstructive pulmonary disease. Immunology. 2019;157:304-11.

59. Bolcas PE, Brandt EB, Zhang Z, Biagini Myers JM, Ruff BP, Khurana Hershey GK. Vitamin D supplementation attenuates asthma development following traffic-related particulate matter exposure. J Allergy Clin Immunol. 2019;143: 386-94 e383.

60. Ivanov II, McKenzie BS, Zhou L, Tadokoro CE, Lepelley A, Lafaille JJ, Cua DJ, Littman DR. The orphan nuclear receptor RORgammat directs the differentiation program of proinflammatory IL-17+ T helper cells. Cell. 2006; 126:1121-33.

61. McGeachy MJ, Chen Y, Tato CM, Laurence A, Joyce-Shaikh B, Blumenschein WM, McClanahan TK, O'Shea JJ, Cua DJ. The interleukin 23 receptor is essential for the terminal differentiation of interleukin 17-producing effector Thelper cells in vivo. Nat Immunol. 2009;10:314-24.

62. Tanaka T, Yamamoto Y, Muromoto R, Ikeda O, Sekine $Y$, Grusby MJ, Kaisho T, Matsuda T. PDLIM2 inhibits T helper 17 cell development and granulomatous inflammation through degradation of STAT3. Sci Signal. 2011;4:ra85

63. Zhao J, Li M, Wang Z, Chen J, Zhao J, Xu Y, Wei X, Wang J, Xie J. Role of PM2.5 in the development and progression of COPD and its mechanisms. Respir Res. 2019;20:120.

64. Maneechotesuwan K, Kasetsinsombat K, Wongkajornsilp A, Barnes PJ. Simvastatin up-regulates adenosine deaminase and suppresses osteopontin 
expression in COPD patients through an IL-13-dependent mechanism Respir Res. 2016;17:104.

65. Halwani R, Sultana A, Al-Kufaidy R, Jamhawi A, Vazquez-Tello A, Al-Muhsen

S. Th-17 regulatory cytokines inhibit corticosteroid induced airway structural cells apoptosis. Respir Res. 2016;17:6.

66. Ciofani M, Madar A, Galan C, Sellars M, Mace K, Pauli F, Agarwal A, Huang W, Parkhurst CN, Muratet M, et al. A validated regulatory network for Th17 cell specification. Cell. 2012;151:289-303.

67. Peters MC, Ringel L, Dyjack N, Herrin R, Woodruff PG, Rios C, O'Connor B, Fahy JV, Seibold MA. A Transcriptomic method to determine airway immune dysfunction in T2-high and T2-Low asthma. Am J Respir Crit Care Med. 2019;199:465-77.

68. Wu J, Zhong T, Zhu Y, Ge D, Lin X, Li Q. Effects of particulate matter (PM) on childhood asthma exacerbation and control in Xiamen, China. BMC Pediatr. 2019:19:194.

69. Xia M, Viera-Hutchins L, Garcia-Lloret M, Noval Rivas M, Wise P, McGhee SA, Chatila ZK, Daher N, Sioutas C, Chatila TA. Vehicular exhaust particles promote allergic airway inflammation through an aryl hydrocarbon receptor-notch signaling cascade. J Allergy Clin Immunol. 2015;136:441-53.

70. Pfeffer PE, Ho TR, Mann EH, Kelly FJ, Sehlstedt M, Pourazar J, Dove RE, Sandstrom T, Mudway IS, Hawrylowicz CM. Urban particulate matter stimulation of human dendritic cells enhances priming of naive CD8 T Iymphocytes. Immunology. 2018;153:502-12.

71. Li T, Hu R, Chen Z, Li Q, Huang S, Zhu Z, Zhou LF. Fine particulate matter (PM2.5): the culprit for chronic lung diseases in China. Chronic Dis Transl Med. 2018;4:176-86.

\section{Publisher's Note}

Springer Nature remains neutral with regard to jurisdictional claims in published maps and institutional affiliations.

Ready to submit your research? Choose BMC and benefit from:

- fast, convenient online submission

- thorough peer review by experienced researchers in your field

- rapid publication on acceptance

- support for research data, including large and complex data types

- gold Open Access which fosters wider collaboration and increased citations

- maximum visibility for your research: over $100 \mathrm{M}$ website views per year

At $\mathrm{BMC}$, research is always in progress.

Learn more biomedcentral.com/submissions 